\title{
PERANCANGAN APLIKASI PENGAMANAN PESAN CHATTING MENGGUNAKAN SOLITAIRE CHIPER BERBASIS ANDROID
}

\section{Tiara Andini}

Program Studi Teknik Informatika, Universitas Budi Darma, Sumatera Utara, Indonesia

Email: tiara@gmail.com

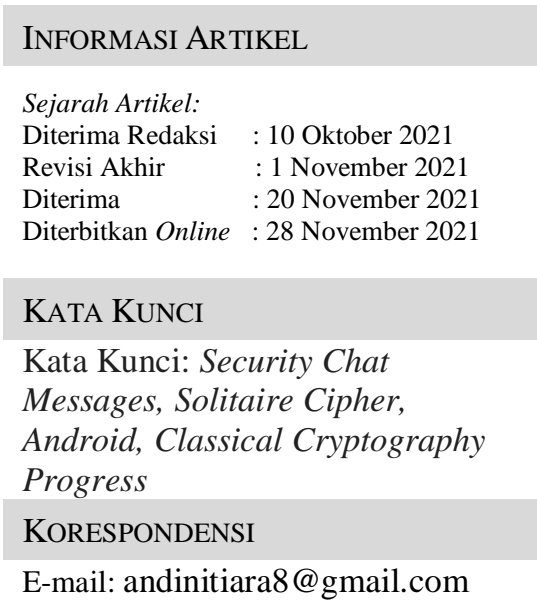

\begin{abstract}
A B S T R A C T
Progress on the delivery of android-based information has many advantages, especially because it can reduce many things that are not necessary or can be said to have an impact on efficiency in many ways. However, along with negative aspects also occur, such as crime, which includes theft, fraud and extortion.

By using the Solitaire Cipher Algorithm which is a classic cryptographic algorithm, which uses playing cards as intermediaries. This type of algorithm uses the order of playing cards as keys that will be securely given to the recipient of the ciphertext. Whereas to do the encryption and decryption process of this solitaire algorithm, the order of cards is changed in certain order and rules.

The design of this application also facilitates the process of securing text so that it is not easily read by others so that the authenticity of the data is maintained. It is an effort to safeguard information from those who are not entitled to access or in other words a confidential information that may not be accessed by others and may only be accessed by those who are granted access.
\end{abstract}

\section{PENDAHULUAN}

Saat ini, teknologi komunikasi dan informasi berkembang dengan pesat dan memberikan pengaruh besar bagi kehidupan manusia. Contoh dari perkembangan ini adalah jaringan internet, yang pada saat ini telah memungkinkan banyak orang untuk saling bertukar data secara bebas melalui jaringan tersebut. Karena kemudahan yang dimilikinya, internet sudah berkembang menjadi salah satu media yang paling populer di dunia. Namun, kemudahan ini juga dimanfaatkan oleh sebagian pihak yang mencoba untuk melakukan kejahatan. Dengan berbagai teknik, banyak yang mencoba untuk mengakses informasi yang bukan haknya. Oleh karena itu, sejalan dengan berkembangnya media internet ini harus juga dibarengi dengan perkembangan sisi keamanan.

Chatting sudah menjadi hal yang umum digunakan oleh masyarakat luas. Kemampuan pengiriman pesan secara cepat membuat user dapat berkomunikasi satu sama lain secara real-time. Selama ini aplikasi tersebut belum bisa menjamin keamanan privasi diantara pengirim dan penerima ketika melakukan obrolan. Untuk menjamin keamanan privasi tersebut dengan melakukan enkripsi pada aplikasi chatting dapat membantu user dalam merahasiakan pesan yang akan dikirimkannya agar terjaga dari orang-orang yang ingin mengetahui isi percakapan si user

\section{METODOLOGI PENELITIAN}

\subsection{Aplikasi}

Aplikasi dapat diartikan sebagai suatu program berbentuk perangkat lunak yang berjalan pada suatu sistem tertentu yang berguna untuk membantu berbagai kegiatan yang dilakukan oleh manusia. Selain pengertian di atas, ada banyak pengertian dari kata 'Aplikasi' yang dikemukakan oleh para ahli[2].

\subsubsection{Pengertian Aplikasi Menurut Para Ahli}

Beberapa pengertian aplikasi menurut para ahli adalah sebagai berikut :

1. Ali Zaki dan Smitdev Community 
Menurut Ali Zaki dan Smitdev Community, Aplikasi merupakan komponen yang bermanfaat sebagai media untuk menjalankan pengolahan data ataupun berbagai kegiatan lainnya seperti pembuatan ataupun pengolahan dokumen dan file.

2. Sri Widianti

Menurut Sri Widianti, Aplikasi merupakan sebuah software (perangkat lunak) yang bertugas sebagai front end pada sebuah sistem yang dipakai untuk mengelolah berbagai macam data sehingga menjadi sebuah informasi yang bermanfaat untuk penggunanya dan juga sistem yang berkaitan.

3. Harip Santoso

Menurut Harip Santoso, Aplikasi merupakan sebuah kelompok file (class, form, report) yang ditujukan sebagai pengeksekusi aktivitas tertentu yang saling berkaitan seperti contohnya aplikasi payroll dan aplikasi fixed asset.

4. Yuhefizar

Menurut Yuhefizar, Aplikasi adalah program yang sengaja dibuat dan dikembangkan sebagai pemenuh kebutuhan penggunanya dalam menjalankan suatu pekerjaan tertentu.

5. Hengky W. Pramana

Menurut Hengky W. Pramana, pengertian aplikasi adalah satu unit perangkat lunak yang sengaja dibuat untuk memenuhi kebutuhan akan berbagai aktivitas ataupun pekerjaan, seperti aktivitas perniagaan, periklanan, pelayanan masyarakat, game, dan berbagai aktivitas lainnya yang dilakukan oleh manusia.

\subsubsection{Sistem Kriptografi}

Sistem Kriptografi memiliki 5 bagian antara lain [6] :

1. Plainteks

Pesan atau data dalam bentuk aslinya yang dapat terbaca. Plainteks adalah masukan bagi algoritma enkripsi.

Untuk selanjutnya digunakan istilah teks asli sebagai padanan kata plainteks.

2. Secret Key

Secret Key juga yang merupakan masukan bagi algoritma enkripsi merupakan nilai yang bebas terhadap teks asli dan menentukan hasil keluaran algoritma enkripsi. Untuk selanjutnya digunakan istilah kunci rahasia sebagai padanan kata secret key

3. Cipherteks

Cipherteks adalah keluaran algoritma enkripsi. Cipherteks dianggap sebagai pesan dalam bentuk tersembunyi.

Algoritma enkripsi yang baik akan menghasilkan cipherteks yang terlihat acak.

4. Enkripsi

Algoritma enkripsi memiliki 2 masukan teks asli dan kunci rahasia. Algoritma enkripsi melakukan transformasi terhadap teks asli sehingga menghasilkan teks sandi.

5. Dekripsi

Algoritma dekripsi memiliki 2 masukan yaitu teks sandi dan kunci rahasia. Algoritma dekripsi memulihkan kembali teks sandi menjadi teks asli bila kunci rahasia yang dipakai algoritma dekripsi sama dengan kunci rahasia yang dipakai algoritma enkripsi.

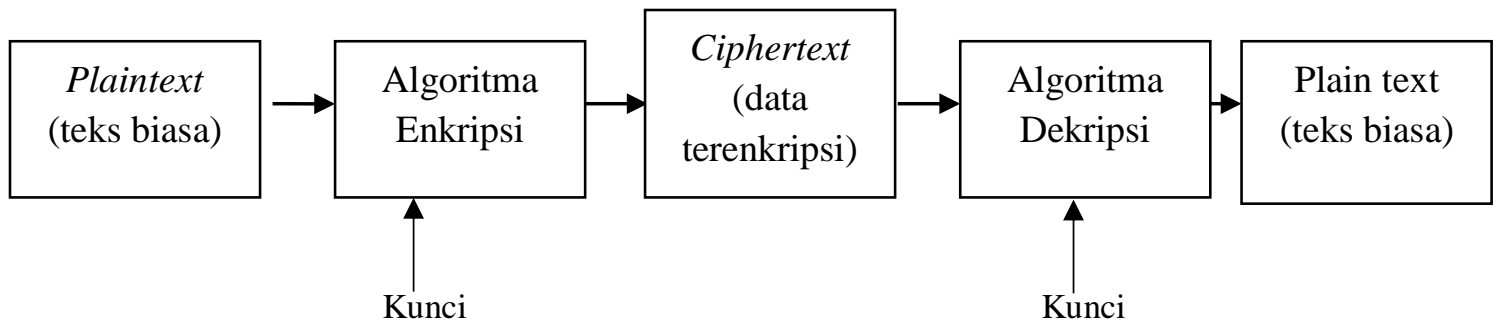

Gambar 1 Proses Enkripsi dan Dekripsi data: Dony Ariyus, 2005 [3]

Prosesnya adalah sebagai berikut:

\section{Proses Enkripsi}

$C=E_{k}(M)$

$\mathrm{C}=$ Chipertext

Enkripsi dengan menggunakan kunci $\mathrm{K}$

$\mathrm{M}=$ Pesan (Message)

Dekripsi dengan menggunakan kunci $\mathrm{K}$
Proses Dekripsi

$M=D_{k}(C)$ keterangan: 


\section{ANALISA DAN PEMBAHASAN}

\subsection{Analisa}

Sub bab ini berisikan tentang analisa sistem yang akan dibangun. Sub bab ini membahas teknik pemecahan masalah yang menguraikan sebuah sistem menjadi bagian-bagian komponen dengan tujuan mempelajari seberapa baik bagianbagian komponen tersebut bekerja dan berinteraksi. Pada proses pengamanan pesan chating memastikan bahwa user (pengguna) dan orang yang berkomunikasi dengan user (pengguna) saja yang dapat membaca apa yang dikirimkan. Pesan-pesan yang akan diamankan (enkripsi) dengan kunci dan hanya penerima dan user (pengguna) saja yang memiliki kunci special yang diperlukan untuk membuka dan membaca pesan yang dikirimkan. Untuk membuka pesan yang telah dikirim si penerima pesan harus melakukan proses dekripsi dan penggunaan kunci yang telah ditentukan oleh user (pengguna) sehingga pesan tersebut dapat dibaca oleh si penerima pesan. Adapun sekenario dari proses pengamanan pesan chatting dapat dilihar pada tabel dibawah ini.

\subsection{Penerapan Algoritma Solitaire Cipher}

Algoritma untuk menghasilkan kunci untuk proses enkripsi dan dekripsi terdiri dari enam langkah. Enam tahap ini akan menghasilkan sebuah angka yang merupakan salah satu bagian aliran kunci. Enam tahap ini kemudian dilakukan kembali untuk mendapatkan kunci kedua dan terus diulang sampai panjang kunci yang diinginkan atau disepakati. Adapun langkah-langkah algoritma soltaire cipher antara lain :

1. Urutkan tumpukan kartu berdasarkan kunci tertentu.

Bagian ini adalah bagian paling penting, karena pihak yang mengetahui sebuah nilai awal dari deck dapat dengan mudah mendapatkannilai yang sama darinya. Bagaimana sebuah tumpukan diinisialisasi terserah oleh penerima. Mengocok kartu dengan benar-benar acak akan lebih baik, walaupun masih ada beberapa metode lain.

Urutan awal seperti ini:

147101316192225283691215182124

27258111417202326

2. Temukan joker A (yang bernilai 27).

Pindahkan satu kartu ke bawah (dengan kata lain, menukar dengan satu kartu dibawahnya). Jika joker tersebut berada di tumpukan paling bawah, pindahkan ke tepat di bawah tumpukan teratas.

Urutan kartu tersebut akan menjadi seperti ini:

147101316192225283691215182124

22758111417202326

3. Temukan joker B (yang bernilai 28).

Pindahkan dua kartu ke bawah. Jika joker tersebut berada pada tumpukan terbawah, pindahkan ke bawah kartu kedua dari atas (jadi kartu ketiga). Jika joker tersebut berada pada posisi kedua dari bawah, pindahkan ke bawah kartu teratas (menjadi kartu kedua).

Setelah langkah ketiga ini, urutan kartu akan menjadi:

147101316192225362891215182124

22758111417202326

4. Lakukan triple cut.

Yaitu ganti kartu-kartu yang berada di bagian kiri kartu joker pertama dengan kartu-kartu di bagian kanan dari kartu joker kedua. Perlu diperhatikan bahwa joker pertama adalah joker yang berada di posisi lebih tinggi dari kartu joker lain, tidak penting apakah itu joker A atau B.

Susunan kartu sebelum triple cut dilakukan:

147101316192225362891215182124

22758111417202326

Susunankartu setelah triple cut dilakukan:

581114172023262891215182124227

14710131619222536

5. Lakukan count cut.

Lihat nilai kartu terbawah, anggap nilai tersebut adalah n. Ambil n kartu pertama dan pindahkan

ke posisi kedua dari bawah.

Susunan kartu sebelum count cut dilakukan:

581114172023262891215182124227

14710131619222536

Susunan kartu setelah count cut dilakukan:

$\begin{array}{lllllllllllllllll}23 & 26 & 28 & 9 & 12 & 15 & 18 & 21 & 24 & 2 & 27 & 1 & 4 & 7 & 10 & 13 & 16\end{array}$

192225358111417206

6. Temukan kartu keluaran.

Untuk melakukan ini, lihat kartu paling atas. Hitung sebanyak nilai kartu tersebut mulai dari kartu setelah kartu paling atas. Nilai kartu pada urutan tersebut adalah nilai berikutnya dalam kunci aliran. 
Pada contoh yang digunakan, nilai kartu paling atas adalah 23. Nilai kartu ke 23 dari kartu setelah kartu paling atas adalah 11. Nilai 11 inilah yang dimasukkan ke dalam kunci aliran. Setelah itu ulangi lagi dari langkah kedua sampai ke enam. Lakukan terus sampai sebanyak panjang kunci yang digunakan. Sebelum mengulang langkah-langkah tersebut, urutan kartu dari proses sebelumnya tidak perlu diubah.

\subsubsection{Proses Enkripsi Dengan Algoritma Solitaire Cipher}

Untuk contoh Implementasi ini, pesan dan kunci yang digunakan harus ditentukan terlebih dahulu. Adapun pesan yang akan diamankan adalah "TIARAANDINI" dengan kunci "BUDIDARMA". Sesuai dengan langkah-langkah enkripsi yang diberikan pada bagian sebelumnya, maka hal yang boertama harus dilakukan adalah pengurutan sesuai dengan kunci yang diberikan. Untuk pengurutan kartu awal ini, langkah yang harus dilakukan adalah

1. Ambil sebuah karakter dari kata kunci untuk contoh implementasi pertama (huruf B) maka

\section{Cut size $=2$}

2. Lakukan enam langkah untuk mendapatkan huruf aliran kunci yang telah dijelaskan dari contoh sebelumnya, maka pengurutan kartu dimulai. Urutan kartu awal dari huruf terkecil ke nilai terbesar. Perlu di ingat kembali bahwa nilai 1-13 diberikan untuk kartu As-kartu king keriting (clubs) secara berurutan. Nilai 14-26 untuk kartu berjenis wajik (diamonds), nilai 27-39 untuk kartu hati (heart) dan nilai 40-52 untuk kartu pohon (spades).

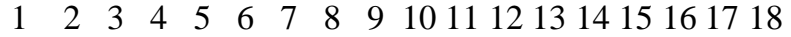

192021222324252627282930313233343536

37383940414243444546474849505152 A B

Langkah pertama adalah pemindahan joker A maka susunan kartu akan menjadi

$\begin{array}{llllllllllllllllll}1 & 2 & 3 & 4 & 5 & 6 & 7 & 8 & 9 & 10 & 11 & 12 & 13 & 14 & 15 & 16 & 17 & 18\end{array}$

192021222324252627282930313233343536

37383940414243444546474849505152 B A

Langkah kedua adalah Pemindahan joker B. Susunan kartu akan berubah menjadi

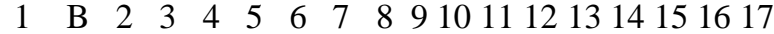

181920212223242526272829303132333435

$3637383940414243444546474849505152 \mathrm{~A}$

Langkah selanjutnya adalah triple cut yang akan menjadi susunan kartu seperti berikut

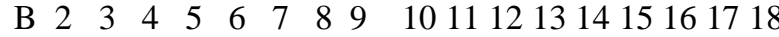

192021222324252627282930313233343536

37383940414243444546474849505152 A 1

Langkah keempat adalah count cut yang akan memindahkan 1 kartu Pertama. Posisi kartu selanjutnya.

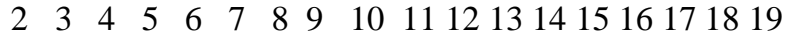

202122232425262728293031323334353637

383940414243444546474849505152 A B 1

Setelah count cut ini, proses pembangkitan aliran kunci untuk penyusunan kartu sesuai kunci telah selesai.

3. Lakukan triple cut. Sejumlah cut_size kartu awal diganti dengan kartu terakhir. Dari hasil di nomor dua, maka posisi urutan kartu berikutnya didapatkan dengan mengganti 2 kartu pertama dengan kartu terakhir.

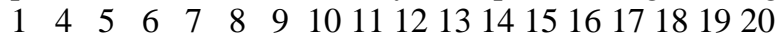

212223242526272829303132333435363738

3940414243444546474849505152 A B 23

4. Lakukan pemindahan kartu berikutnya, dengan meletakan kartu pertama sebagai kartu paling bawah. Posisi kartu lain tidak diubah.

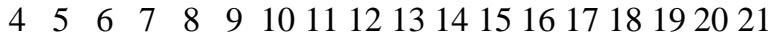

222324252627282930313233343536373839

40414243444546474849505152 A $\quad$ B $2 \quad 3 \quad 1$

Dengan demikian proses untuk mendapatkan susunan kartu menurut karakter pertama dari kunci telah dilakukan. Langkah-langkah diatas diulangi untuk semua karakter lain dari kata kunci. Selanjutnya akan dicontohkan pengaturan kunci untuk karakter kedua, yaitu U. susunan kartu awal untuk karakter U ini diambil dari susunan yang dihasilkan untuk pengaturan kartu berdasarkan karakter B. maka sususnan awal pengaturan kunci untuk karakter U ini adalah

$\begin{array}{llllllllllllllllll}4 & 5 & 6 & 7 & 8 & 9 & 10 & 11 & 12 & 13 & 14 & 15 & 16 & 17 & 18 & 19 & 20 & 21\end{array}$

222324252627282930313233343536373839

40414243444546474849505152 A $\quad$ B $2 \quad 3 \quad 1$

Langkah-langkahnya adalah :

1. Penentuan cut_size

Cut_size $=21$

2. Enam langkah mendapatkan aliran kunci, hasil dari pergeseran joker A

$\begin{array}{lllllllllll}4 & 5 & 6 & 7 & 8 & 9 & 1011 & 12131415161718192021\end{array}$

222324252627282930313233343536373839

40414243444546474849505152 B A $2 \quad 3 \quad 1$

Hasil dari penggeseran joker $\mathrm{B}$ :

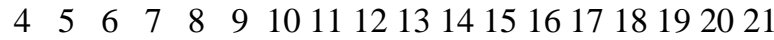

222324252627282930313233343536373839 
40414243444546474849505152 A 2 B 31

Hasil dari triple cut :

$31 \mathrm{~A} \quad 2 \quad \mathrm{~B} \quad 4 \quad 5 \quad 5 \quad 6 \quad 7 \quad 8 \quad 9610111213141516$ 171819202122232425262728293031323334 353637383930414243444546474849505152 Hasil dari count cat :

$\begin{array}{llllllllllllllllll}51 & 3 & 1 & \mathrm{~A} & 2 & \mathrm{~B} & 4 & 5 & 6 & 7 & 8 & 9 & 10 & 11 & 12 & 13 & 14 & 15\end{array}$ 161718192021222324252627282930313233 343536373839304142434445464748495052

3. Triple cut

Hasil dari triple cut :

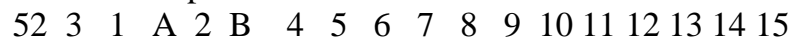
161718192021222324252627282930313233 343536373839304142434445464748495051

4. Pemindahan kartu pertama Hasilnya ;

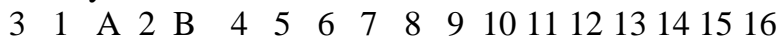
171819202122232425262728293031323334 353637383940414243444546474849505152 Penyusunan kartu untuk karakter (D) :

Susunan kartu awal

$\begin{array}{llllllllllllllllll}3 & 1 & \mathrm{~A} & 2 & \mathrm{~B} & 4 & 5 & 6 & 7 & 8 & 9 & 10 & 11 & 12 & 13 & 14 & 15 & 16\end{array}$ 171819202122232425262728293031323334 353637383940414243444546474849505152

Langkah yang dilakukan :

1. Penentuan cut_size cut_size $=3$

2. Enam langkah mendapatkan aliran kunci.

Hasil dari penggeseran joker A :

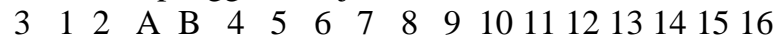
171819202122232425262728293031323334 353637383940414243444546474849505152 Hasil dari penggeseran joker B :

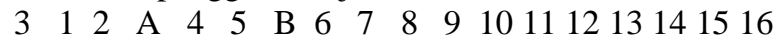
171819202122232425262728293031323334 353637383940414243444546474849505152 Hasil dari triple cut :

$6 \begin{array}{llllllll}6 & 7 & 8 & 9 & 1011 & 121314151617181920212223\end{array}$ 242526272829303132333435363738394041 4243444546474849505152 A $4 \quad 5 \quad$ B $3 \quad 12$ Hasil count cat $8 \quad 9 \quad 10111213141516171819202122232425$ 262728293031323334353637383940414243 444546474849505152 A 45 B $3 \quad 1672$

3. Triple cut

Hasil dari triple cut :

21112131415161718192021222324252627 282930313233343536373839404142434445

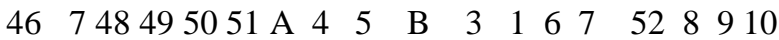

4. Pemindahan kartu pertama, hasil nya :

111213141516171819202122232425262728 293031323334353637383940414243444546

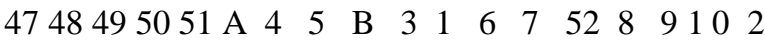

Penyusunan berikutnya adalah penyusunan karakter keempat. Yaitu I. susunan kartu awal untuk karakter I : 111213141516171819202122232425262728 293031323334353637383940414243444546

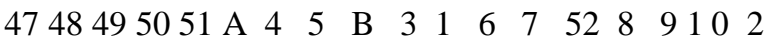

Langkah untuk menyusun kartu :

1. Penentuan cut_size $=9$

2. Enam langkah mendapatkan aliran kunci.

Hasil dari penggeseran joker A :

111213141516171819202122232425262728

293031323334353637383940414243444546

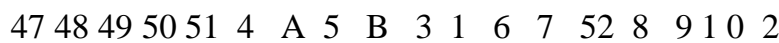


Hasil dari penggeseran joker B :

111213141516171819202122232425262728 293031323334353637383940414243444546 47484950514 A $5 \quad 31$ B 6775289102 Hasil dari triple cut :

$67528 \quad 9102$ A $5 \quad 31$ B 111213141516 171819202122232425262728293031323334 35363738394041424344454647484950514 Hasil dari count cut :

A 531 B 11121314151617181920212223 2425262728293031323334353637383940 4142434445464748495051406752809102

3. Triple cut :

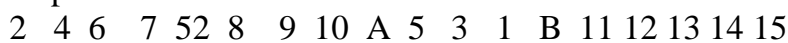
161718192021222324252627282930313233 343535363738394041424344454647484950514

4. Pemindahan kartu pertama

Hasilnya :

$467528 \quad 910$ A $5 \quad 3 \quad 1 \quad$ B 11121314151617 18192021222324252627282930313233343535 3637383940414243444546474849505142

Penyusunan kartu untuk karakter kelima (D)

Dimulai dengan sususnan kartu :

$4675528 \quad 910$ A $5 \quad 3 \quad 1 \quad$ B 11121314151617 18192021222324252627282930313233343535 3637383940414243444546474849505142

Langkah untuk penyusunan kartu :

1. Penentuan cut_size $=4$

2. Enam langkah mendapatkan aliran kunci.

Hasil dari penggeseran joker $\mathrm{A}$ :

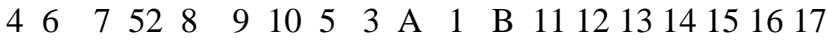
18192021222324252627282930313233343535 3637383940414243444546474849505142

Hasil dari penggeseran joker B :

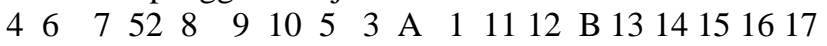
18192021222324252627282930313233343535 363738394041424344454647484950512

Hasil dari triple cut :

131415161718192021222324252627282930 313233343535363738394041424344454647 4849505142 A 111112 B $46 \quad 7528 \quad 91053$ Hasil dari count cut ;

B $46 \begin{array}{lllllll}6 & 52 & 8 & 9 & 10 & 531314 & 1516171819202122\end{array}$ 232324252627282930313233343535363738 383940414243444546474849505142 A 11112

3. Triple cut Hasil dari triple cut sususnan kartu :

$12528 \quad 910531314151617181920212223 \quad 23$

2425262728293031323334353536373839 40414243444546474849505142 A 1 B 11

4. Pemindahan kartu pertama, hasilnya :

528910531314151617181920212223224 2526272829303132333435353637383940 414243444546474849505142 A 1 B 1112

Selanjutnya adalah penyusunan kartu berdasarkan karakter A susunan awal kartunya: 528910531314151617181920212223224 2526272829303132333435353637383940 414243444546474849505142 A 1 B 1112

1. Penentuan cut_size

$$
\text { Cut_size }=1
$$

2. Penggerakan joker A. hasilnya :

528910531314151617181920212223224 2526272829303132333435353637383940 $414243444546474849505142 \quad 1$ A B 1112 
Penggeseran joker B. hasilnya :

528910531314151617181920212223224

25262728293031323334353637383940

$414243444546474849505142 \quad 1$ A 1112 B

Triple cut :

52 A 1112 B 91053131415161718192021

22232242526272829303132333435363738

$3940414243444546474849505142 \quad 1$

Count cut ;

B 9105313141516171819202122232442

2526272829303132333435363738394041

4243444546474849505152 A 11121

3. Triple cut :

1 A 1112 B 91053131415161718192021

22232442252627282930313233343536

3637383940414243444546474849505152

4. Hasil dari pemindahan kartu pertama

A 1112 B 9105313141516171819202122

23244225262728293031323334353637

$3839404142434445464748495051 \quad 52 \quad 1$

Penyusunan berikutnya dimulai dengan sususnan :

A 1112 B 9105313141516171819202122

23244225262728293031323334353637

$3839404142434445464748495051 \quad 52 \quad 1$

1. Penentuan cut size $=18$

2. Hasil dari penggeseran joker A ;

11 A 12 B 9105313141516171819202122

23244225262728293031323334353637

$383940414243444546474849505152 \quad 1$

Penggeseran joker B ;

11 A 12910 B 5313141516171819202122

23244225262728293031323334353637

$383940414243444546474849505152 \quad 1$

Triple cut :

B 53131415161718192021222324422526

27 A 129102829303132333435363738

$3940414243444546474849505152 \quad 111$

Count cut :

5313141516171819202122232442252627

A 1291028293031323334353637383940 $414243444546474849505152 \quad 1$ B 11

3. Triple cut

1112 A 91028293031323334353637383940

5313141516171819202122232442252627

$414243444546474849505152 \quad 1$ B

4. Pemindahan kartu pertama

129 A 10282930313233343536373839405

313141516171819202122232442252627

$414243444546474849505152 \quad 1$ B 11

Selanjutnya penyusunan kartu berdasarkan karakter R. susunan awal kartunya :

129 A 10282930313233343536373839405

313141516171819202122232442252627

$414243444546474849505152 \quad 1$ B 11

Langkah-langkah penyusunan kartu ;

1. Penentuan nilai cut_size

Cut_size $=9$

2. Empat langkah pembangkitan aliran kunci.

Pertama, penggesran joker A :

12910 A 282930313233343536373839405

313141516171819202122232442252627

$414243444546474849505152 \quad 1$ B 11

Kedua, penggeseran joker B :

12 B 910 A 282930313233343536373839

40531314151617181920212223244225 
$2627414243444546474849505152 \quad 111$

Ketiga, triple cut :

910 A 2829303132333435363738394053

1314151617181920212223244225262741

$4243444546474849505152 \quad 11112$ B

Keempat, count cut :

383940531314151617181920212223244

2 A 282930313233343536372526274142

$434445464748 \quad 495051 \quad 9 \quad 1052 \quad 11112$ B

3. Triple cut

B 29303132333435363725262741424344

$45464748495051 \quad 9 \quad 1052 \quad 111123839405$

313141516171819202122232442 A 28

4. Pemindahan kartu pertama

29303132333435363725262741424344

45464748495051910521111123839405

313141516171819202122232442 A 28 B

Selanjutnya adalah proses penyusunan kartu terakhir dengan dengan karakter M. susunan kartu awlnya sama dengan susunan terakhir yang dihasilkan oleh penyusunan kartu dengan karakter A yaitu ;

29303132333435363725262741424344

45464748495051910521111123839405

313141516171819202122232442 A 28 B

Langkah-langkah penyusunan kartu :

1. Penentuan nilai cut size

Cut_size $=1$

2. Empat langkah pembangkitan aliran kunci.

Pertama, penggeseran joker A :

03132333435363725262741424344

$45464748495051901052 \quad 111123839405$

31314151617181920212223244228 A B

Kedua, penggeseran joker B:

30 B 3132333435363725262741424344

$4546474849505191052 \quad 111123839405$

31314151617181920212223244228 A 29

Ketiga , triple cut :

B 31323334353637252627414243444546

$474849505191052 \quad 111123839405313$

14151617181920212223244228 A 2930

Keempat, count cut :

3725262741424344454647484950519

1052 B 313233343536111123839405313

14151617181920212223244228 A 2930

3. Triple cut

3049505191052 B 313233343536372526

274142434445464748495051111123839

40531314151617181920212223244228 A 29

Pemindahan kartu pertama

49505191052 B 31323334353637252627

414243444546474849505111112383940

31314151617181920212223244228 A 30

Dengan demikian proses pengurutana

Kartu awal telah selesai.susunan kartu yang terakhir dihasilkan sudah bisa digunakan untuk melakukan enkripsi pesan Proses selanjutnya adalah penjumlahan keystream dengan plainteks antara lain :

1. Penentuan nilai dari kartu keluaran untuk kunci $\mathbf{B}$

Nilai keluaran $=$ nilai kartu pada posisi $($ nilai kartu pertama +1$)$.dengan demikian posisi kartu keluaran adalah pada $(4+1)=5$.

Maka kartu keluaran adalah pada posisi 5. Nilai kartu pada posisi 5 tersebut adalah 9. Kartu dengan nilai 9 adalah Sembilan As. Sehingga hasilnya adalah

Nilai keluaran $=9$

Kartu keluaran $=$ Sembilan As.

2. Penentuan nilai dari kartu keluaran untuk kunci $\underline{\mathbf{U}}$

Nilai keluaran $=$ nilai kartu pada posisi $($ nilai kartu pertama +1$)$.dengan demikian posisi kartu keluaran adalah pada $(3+1)=4$. 
Maka kartu keluaran adalah pada posisi 4. Nilai kartu pada posisi 4 tersebut adalah joker B atau sama dengan nilai 54. Kartu dengan nilai 54 adalah joker B. Sehingga hasilnya adalah

Nilai keluaran $=54$

Kartu keluaran $=$ joker $\mathrm{B}$

3. Penentuan nilai dari kartu keluaran untuk kunci $\underline{\mathbf{D}}$

Nilai keluaran $=$ nilai kartu pada posisi $($ nilai kartu pertama +1$)$.dengan demikian posisi kartu keluaran adalah pada $(11+1)=12$.

Maka kartu keluaran adalah pada posisi 12. Nilai kartu pada posisi 12 tersebut adalah 23. Kartu dengan nilai 23 adalah Sepuluh Wajik. Sehingga hasilnya adalah

Nilai keluaran $=10$

Kartu keluaran $=$ Sepuluh wajik

4. Penentuan nilai dari kartu keluaran untuk kunci $\underline{\mathbf{I}}$

Nilai keluaran = nilai kartu pada posisi $($ nilai kartu pertama +1$)$.dengan demikian posisi kartu keluaran adalah pada $(4+1)=5$.

Maka kartu keluaran adalah pada posisi 5. Nilai kartu pada posisi 5 tersebut adalah 9. Kartu dengan nilai 9 adalah Sembilan As. Sehingga hasilnya adalah

Nilai keluaran $=9$

Kartu keluaran $=$ Sembilan As

5. Penentuan nilai dari kartu keluaran untuk kunci $\underline{\mathbf{D}}$

Nilai keluaran = nilai kartu pada posisi (nilai kartu pertama +1$)$.dengan demikian posisi kartu keluaran adalah pada $(52+1)=53$.

Maka kartu keluaran adalah pada posisi 53. Nilai kartu pada posisi 53 tersebut adalah 12. Kartu dengan nilai 12 adalah pro As. Sehingga hasilnya adalah

Nilai keluaran $=12$

Kartu keluaran $=$ pro As

6. Penentuan nilai dari kartu keluaran untuk kunci $\underline{\mathbf{A}}$

Nilai keluaran $=$ nilai kartu pada posisi $($ nilai kartu pertama +1$)$.dengan demikian posisi kartu keluaran adalah pada (joker A atau $53+1)=54$.

Maka kartu keluaran adalah pada posisi 54. Nilai kartu pada posisi 54 tersebut adalah joker B atau bernilai 54. Kartu dengan nilai 54 adalah pro As.karena melebihi 26, maka nilainya dikurangi 26 menjadi 28.Sehingga hasilnya adalah

Nilai keluaran $=28$

Kartu keluaran $=$ dua hati

7. Penentuan nilai dari kartu keluaran untuk kunci $\underline{\mathbf{R}}$

Nilai keluaran $=$ nilai kartu pada posisi $($ nilai kartu pertama +1$)$.dengan demikian posisi kartu keluaran adalah pada $(12+1)=13$.

Maka kartu keluaran adalah pada posisi 13. Nilai kartu pada posisi 13 tersebut adalah 37. Kartu dengan nilai 37 adalah jack hati. .karena melebihi 26, maka nilainya dikurangi 26 menjadi 11. Sehingga hasilnya adalah

Nilai keluaran $=11$

Kartu keluaran $=$ jack As

8. Penentuan nilai dari kartu keluaran untuk kunci $\underline{\mathbf{M}}$

Nilai keluaran $=$ nilai kartu pada posisi $($ nilai kartu pertama +1$)$.dengan demikian posisi kartu keluaran adalah pada $(29+1)=30$.

Maka kartu keluaran adalah pada posisi 30. Nilai kartu pada posisi 30 tersebut adalah 39. Kartu dengan nilai 39 adalah king hati. .karena melebihi 26, maka nilainya dikurangi 26 menjadi 13. Sehingga hasilnya adalah

Nilai keluaran $=13$

Kartu keluaran $=$ king As

9. Penentuan nilai dari kartu keluaran untuk kunci $\underline{\mathbf{A}}$

Nilai keluaran $=$ nilai kartu pada posisi $($ nilai kartu pertama +1$)$.dengan demikian posisi kartu keluaran adalah pada $(49+1)=50$.

Maka kartu keluaran adalah pada posisi 50. Nilai kartu pada posisi 50 tersebut adalah 28. Kartu dengan nilai 28 adalah dua hati. karena melebihi 26, maka nilainya dikurangi 26 menjadi 2. Sehingga hasilnya adalah

Nilai keluaran $=2$

Kartu keluaran $=$ dua As

Setelah Sembilan kali pembangkitan keystream yang dilakukan di atas, maka keystream yang didapatkan adalah

B U D I D A R M A

$\begin{array}{lllllllll}9 & 54 & 10 & 9 & 12 & 28 & 11 & 13 & 2\end{array}$

Dengan plainteks

T I A R A A $\mathrm{N}$ D

$\begin{array}{lllllllllll}20 & 9 & 1 & 18 & 1 & 1 & 14 & 4 & 9 & 14 & 9\end{array}$

Maka penjumlahannya adalah

$\begin{array}{lllllllll}9 & 54 & 10 & 9 & 12 & 28 & 11 & 13 & 2\end{array}$

$\begin{array}{lllllllllll}20 & 9 & 1 & 18 & 1 & 1 & 14 & 4 & 9 & 14 & 9\end{array}+(\bmod 26)$ 


\section{$\begin{array}{lllllllllll}3 & 11 & 11 & 1 & 13 & 3 & 25 & 17 & 11 & 14 & 9\end{array}$}

$\begin{array}{llllllllllllllllllll}\mathbf{C} & \mathbf{K} & \mathbf{K} & \mathbf{A} & \mathbf{M} & \mathbf{C} & \mathbf{Y} & \mathbf{Q} & \mathbf{K} & \mathbf{N} & \mathbf{I}\end{array}$

Maka cipherteksnya adalah

$$
\begin{array}{lllllllllllllll}
\mathbf{C} & \mathbf{K} & \mathbf{K} & \mathbf{A} & \mathbf{M} & \mathbf{C} & \mathbf{Y} & \mathbf{Q} & \mathbf{K} & \mathbf{N} & \mathbf{I}
\end{array}
$$

\section{i. Proses Deskripsi Dengan Algoritma Soltaire Cipher}

Untuk proses deskripsi, dua langkah yang harus dilakukan sama dengan dua langkah pertama enkripsi. Jika pada enkripsi keystream dijumlahkan dengan plainteks, maka pada deskripsi chiperteks dikurangi dengan keystream. Untuk contoh di atas, setelah mendapatkan keystream.
B U D I D A R M A
$\begin{array}{lllllllll}9 & 54 & 10 & 9 & 12 & 28 & 11 & 13 & 2\end{array}$
Maka chiperteknya adalah
$\begin{array}{lllllllllll}C & \mathrm{~K} & \mathrm{~K} & \mathrm{~A} & \mathrm{M} & \mathrm{C} & \mathrm{Y} & \mathrm{Q} & \mathrm{K} & \mathrm{N} & \mathrm{I}\end{array}$
$\begin{array}{lllllllllll}3 & 11 & 11 & 1 & 13 & 3 & 25 & 17 & 11 & 14 & 9\end{array}$

Dikurangi dengan keystream tersebut. Hasilnya

$\begin{array}{lllllllllllllllllll}\text { C } & \mathrm{K} & \mathrm{K} & \mathrm{A} & \mathrm{M} & \mathrm{C} & \mathrm{Y} & \mathrm{Q} & \mathrm{K} & \mathrm{N} & \mathrm{I}\end{array}$

$\begin{array}{llllllllll}9 & 54 & 10 & 9 & 12 & 28 & 11 & 13 & 2\end{array}$

$\begin{array}{llllllllllll}3 & 11 & 11 & 1 & 13 & 3 & 25 & 17 & 11 & 14 & 9 & -(\bmod 26)\end{array}$

Adalah :

$\begin{array}{lllllllllll}20 & 9 & 1 & 18 & 1 & 1 & 14 & 4 & 9 & 14 & 9\end{array}$

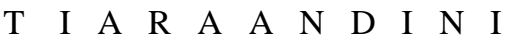

Dari hasil deskripsi, penerima bisa menebak apakah karakter terakhir adalah karakter padding atau tidak.

\section{IMPLEMENTASI}

\subsection{Hasil}

1. Tampilan Aplikasi Chatting

Keterangan :

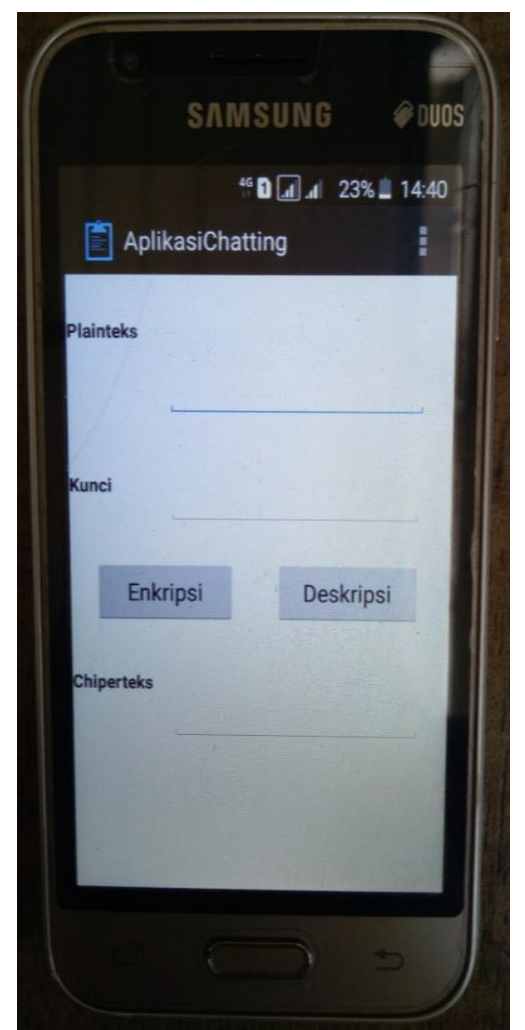

Gambar 2 Tampilan Aplikasi Chatting

1. Textbox pada plainteks berfungsi untuk memasukan pesan yang akan digunakan untuk enkripsi.

2. Textbox kunci berfungsi untuk kunci pesan pada plainteks

3. Button enkripsi digunakan untuk proses enkripsi pesan pada plainteks.

4. Button deskripsi digunakan untuk mengembalikan hasil enkripsi

5. Textbox chiperteks berfungsi untuk menampung hasil dari enkripsi dan deskripsi. 


\subsection{Tampilan Output}

1. Tampilan Proses Enkripsi

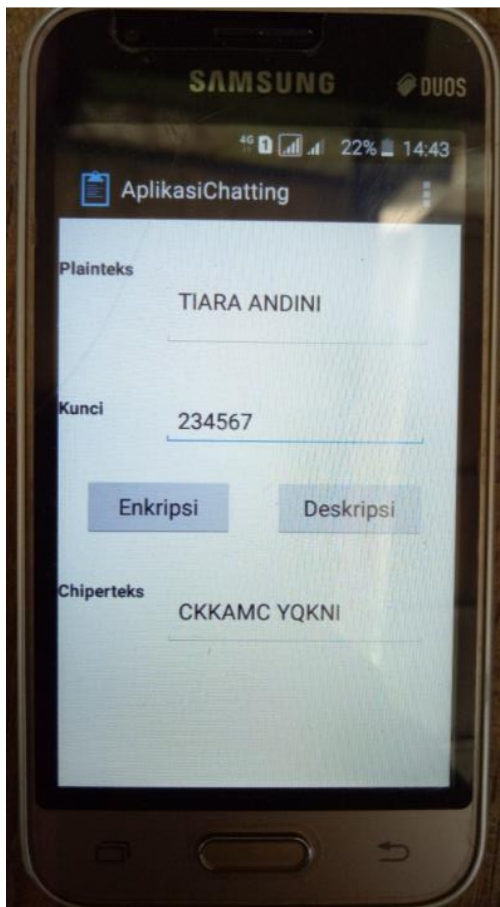

Gambar 3 Tampilan Proses Enkripsi

2. Tampilan Proses Deskripsi

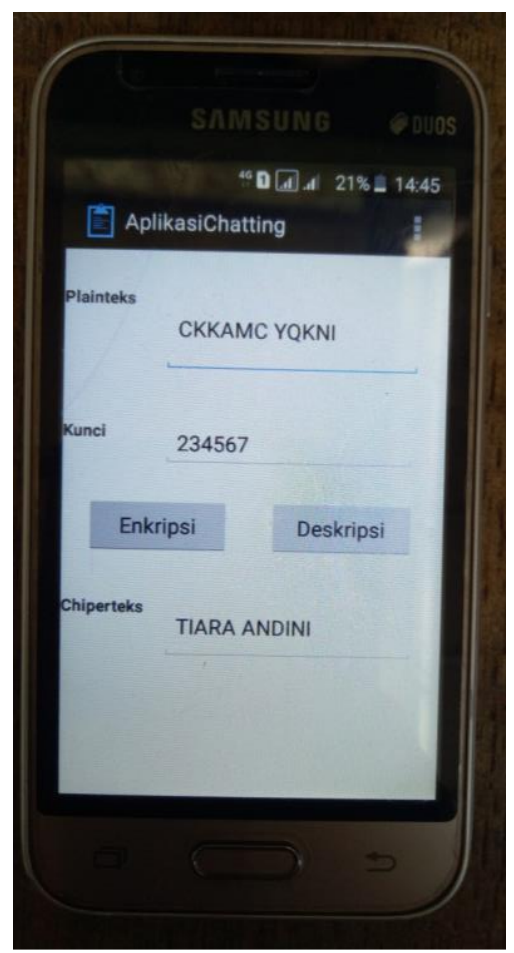

Gambar 4 Tampilan Proses Deskripsi

\section{KESIMPULAN}

Setelah menyelesaikan skripsi yang berjudul perancangan aplikasi pengamanan pesan chatting menggunakan solitaire cipher berbasis android, dapat ditarik beberapa kesimpulan sebagai berikut :

1. Dalam pengujian Aplikasi ini berhasil mengamankan pesan pengguna yang dikirim melalui pesan chating.

2. Aplikasi dapat memproses Pesan teks minimal 12 karakter dengan kunci 128 bit

3. Penerapan metode pengamanan data pada plainteks dilakukan untuk menyembunyikan rahasia pada saat pendistribusian pesan rahasia, yaitu dengan cara simetris yang dilakukan melalui proses dekripsi. Dimana data 
pada plainteks awalnya diproses melalui kunci enkripsi, lalu data dialirkan menjadi kunci dekripsi sehingga akhirnya menjadi teks/data asli yang aman.

\section{REFERENCES}

[1] Baez, Jeffrey, 2009, "Math In The Solitaire Cipher”,Journal IEEE Trans. On Computer, Vol. 58, No. 6, pp.721-727.

2] http://www.e-jurnal.com/2014/02/pengertian-pesan.html, diakses tanggal 24 Mei 2018.

[3] https://www.maxmanroe.com/vid/teknologi/pengertian-chatting.html,diakses tanggal 24 April 2018

[4] Ariyus, Dony, 2005, "Kriptografi Keamanan Data Dan Komunikasi”. Edisi Pertama. Yogyakarta. Graha Ilmu.

[5] Sadikin, Rifki, 2012, "Kriptografi Untuk Keamanan Jaringan", Penerbit Andi, Yogyakarta.

[6] Ariyus, Dony, 2008, "Computer Security, Andi, Yogyakarta.

[7] https://www.maxmanroe.com/vid/teknologi/pengertian chatting.html,diakses tanggal 24 April 2018.

[8] A.S. Rosa dan Shalahuddin. M, 2013, "Rekayasa Perangkat Lunak Terstruktur”, Andi, Yogyakarta. 